\title{
THE EFFECT OF SUMMARIZATION INSTRUCTIONAL STRATEGIES AND PRESENTATION FORMATS ON THE OUTCOMES OF HISTORICAL ARGUMENTATIVE REASONING
}

\author{
Susanto Yunus Alfian \\ SMA Negeri 1 Sumberpucung, Malang. \\ susantoyunusalfian@yahoo.com
}

\begin{abstract}
The purpose of this research is to examine the effects of summarization instructional strategies and presentation formats on the learning outcomes of history argumentative reasoning. This study is designed as a factorial design. The subjects were the students enrolled in four stateowned sehior high school in Malang Regency. The main conclusions are presented as follow: (1) A significant difference existed for students who used the cause-effect graphic organizer summarization strategy to answer history argumentative reasoning post-test questions when compared to the written summarizing strategy, (2) There is no difference between those who were presented with present-subheadings presentation format and those who were presented absentsubheadings on answering history argumentative reasoning posttest questions, and (3) There is a significant interaction between the summarization instructional strategies and the presentation formats. The students who used cause-effect graphic organizer summarization strategy and were given with the present-subheadings presentation format significantly outperformed in the historical argumentative reasoning post-test scores than the other groups (graphic organizer and absent-subheadings group, written summarizing and with-subheadings group, and written summarizing and without-subheadings group).
\end{abstract}

Key Words: summarization instructional strategy, presentation format, cause-effect graphic organizer, written summarizing, presentsubheadings, historical argumentative reasoning.
ABSTRAK

Tujuan dari penelitian ini adalah untuk mengetahui pengaruh strategi pembelajaran summarization dan format presentasi tentang hasil belajar sejarah penalaran argumentatif. Penelitian ini dirancang sebagai desain faktorial. Subjek penelitian adalah siswa terdaftar di empat sekolah SMA di Kabupaten Malang. Kesimpulan utama disajikan sebagai berikut: (1) Sebuah perbedaan yang signifikan ada bagi siswa yang menggunakan strategi peringkasan untuk menjawab sejarah argumentatif pertanyaan penalaran posttest bila dibandingkan dengan strategi meringkas tertulis, (2) Tidak ada perbedaan antara mereka yang disajikan dengan saatsubpos format presentasi dan mereka yang disajikan absen-subpos pada menjawab sejarah penalaran argumentatif pertanyaan posttest, dan (3) Ada interaksi yang signifikan antara strategi pembelajaran peringkasan dan format presentasi. Para siswa yang menggunakan sebab strategi pengelolaan peringkasan dan diberi dengan format presentasi signifikan mengungguli dalam skor penalaran posttest sejarah argumentatif daripada kelompok lain (pengelolaan grafis dan kelompok tanpa anak judul, meringkas tertulis dan kelompok dengan anak judul, dan meringkas tertulis dan kelompok tanpa anak judul).

Kata Kunci: strategi pembelajaran peringkasan, presentasi, pengelolaan grafik sebab-akibat, ringkasan tertulis, presentasi, , format presentasi, sebab-akibat, tidak ada-subpos, penalaran argumentatif sejarah. 


\section{INTRODUCTION}

Till recently, the history instruction in Indonesia as a verbal instruction emphasizes the cognitive aspect (Senen \& Barnabib, 2000). In Malang District, government-coordinated summative evaluations still stresses on multiple choice tests. In addition the items of the tests are dominated by lower cognitive levels. Historical thinking as being stressed by Permendikbud about Curriculum Structure of SMA/MA No. 69/ 2013 is a higher level of cognitive domain (Duron et al., 2006). Cognitive skills and mental abilities are interpretation, analysis, evaluation, inference, explanation and self-regulation (Facione, 2007). Explanation is the presentation of the reasoning product. Sub-skills of explanation are method and result descriptions, determining a procedure, making a conceptual and causal description of events, making argumentative argument. The ability to argue is an important part of history subject matter. History teachers rarely discuss the outcomes of historical reasoning. At least, I, as a member of Malang District History Teacher Club, experience this. The history teachers still do not move on to the "reasoning paradigm".

In the history classes, it is important to explain why the past happened the way it did. The historical event did not happen by itself. The students need to know the factors and the effects of the historical event. In other words, they need to know the order of and the connections between distinct but related events. The chain of events shapes or causes the other event consequences. If the teachers ask them to answer why the past happened, they ask the students to do historical reasoning. When the students learn why, meaningful learning in school history classes will happen.
Understanding texts is an important focus for studying history, because a text is one of the main sources (Baker, 1994). To understand a text, they needs strategies (Massey \& Heafner, 2004; Key et al., 2010). When reading a historical text, students do reasoning and interpreting (Paxton, 1999). When reading, students can grasp an argument (Rael, 2005). Reading strategy focusing on key concepts and information in history can increase understanding (de la Pas et al., 2007). The purpose of reading in primary documents or textbooks is reading comprehension (Neumann, 2010). Wineburg (1991) stated that history subjectmatter has potentials to enhance thinking and reasoning. When reading texts, students think human motives, search truths, and deepen social world. Reading texts is the most important activity in the history teaching (van Sledright, 2009).

Research on learning history has focused on concept acquisition, causal reasoning, and learning form text (Voss \& Wiley, 1995). Beside that, historical instruction shifts from the content to reasoning and strory construction (van Drie \& van Boxtel, 2008; Yilmas, 2009). This research emphasizes causal reasoning as a historical argumentative reasoning. In this research either, two summarizing strategies (visual summarizing as a graphic organizer and written summarizing) are used.

In the verbal information teaching, the history textbooks are important in the instructional process. History teachers have many choices to select them. The presentation formats of the books are different (Sekretariat Negara RI 1986; Supriatna, 2007; Alfian et al., 2007; Iskandar et al., 2007; and Mustopo et al., 2008). The different formats of the texts are attracting to investigate.

Sub-headings presentation format had been studied by some researchers. 
Sub-headings can enhance retention and multiple choice test scores (Wilhite, 1988). It can facilitate retention on main ideas (Wilhite, 1986; Wilhite, 1989). Clariana \& Marker (2007) studied subheadings in facilitating structural knowledge in screen.

Summarizing as a strategy of reading (de Ramos, 2010; Presley, 2000) consists of oral, written and visual summarization (Neufeld, 2005). Oral summarization is to check what have been read by the students. A visual summarizations as a visual organizer reveals idea relations. Written summary is the shorter text condensed from the original text. A summary contains important ideas, not trivial details (Taylor, 1986). Summarization provides cognitive shopping bags: students who group ideas into schemata and label the schemata and the relationship among them have a reasonable number of schemata to keep in mind instead of an unmanageably large aggregation of discrete ideas (Friend, 2001).

As a strategy of summarization, a number of studies have documented the betterment of graphic organizer. DiCecco \& Gleason (2002) investigated the effect of graphic organizer to relational knowledge. Kools et al., (2006) examined the effect of graphic organizer to objective and subjective comprehension, recall and transfer. According to Kang (2004) graphic organizer can help students to get, to explain and to communicate information, and they can visualize concepts. Graphic organizer can help students to understand social studies texts mainly recall and recognition (Armbruster et al., 1991). Graphic organizer can enhance math learning (Braselton \& Decker, 1994). By using graphic organizer, students get more coordinate and hierarchical relation than students in outline (Robinson \& Schraw, 1994; Robinson \& Kiewra,
1995). From a metanalysis of studies, Kim et al., (2004) concluded that graphic organizer helps students comprehend better than the other strategies.

But the other studies showed different results. Darch et al. (1986) proved that graphic organizer is as effective as the other strategies. Trevino (2005) proved that outlining is better than graphic organizer in the form of mind mapping.

Similarly, written summarizing as a summarization strategy also attractes researchers. This strategy can increase student abilities to use keywords, select information sources, and search the content of a text (Hwang \& Kuo, 2011). Written summarizing can effectively help students to answer factual questions (Gajria \& Salvia, 1992). Written summarizing can increase in comprehending texts than the traditional one (Malone \& Mastropieri, 1991). Written summarizing can help better in free recall, objective tests and essay tests than self-prequestioning strategy (King et al., 1998). In short, the results showed in consistency.

There are some considerations to investigate graphic organizer as a summarization strategy in history. Graphic organizer can make meaningful learning happen (Hill, 2005). Graphic organizer is useful to develop the cognitive domain (Mitchel \& Hutchinson, 2003). Graphic organizer can increase comprehension (Zaini et al., 2010). Graphic organizer is an operationalization of mental models (Spicer, 1998). By using graphic organizer, students can write better and need shor time (Sirias, 2002). Graphic organizer can be an effective tool to help students get main concepts (MarchanMartela et al., 1998). Graphic organizer represents an organizational structure of a text (simple listings, time ordering, comparison/contrast, and cause and effect (Alvermann, 1986) or the frame or 
the structure of text content (Chang, 2007).

Thus, constructing graphic organizer is important to be investigated. In the graphic organizer, students acquire, store, and retrieve more relational knowledge, so they can answer essay tests better (DiCecco \& Gleason, 2002). By constructing a graphic organizer, as a verbal and visuo spatial memory, students will easily recall main ideas (Nesbit \& Adesope, 2006). Mapping can be a template and scaffold to organize knowledge (Novak \& Canas, 2008). Matrix as a graphic organizer makes conceptual relations more explicitly, so that the students easily learn the relations and encode information (Robinson \& Schraw, 1994). Displayed-texts are encoded in verbal and spatial memory and the spatial memory will be a second stratum cue when the verbal recall fails (Robinson \& Schraw, 1994).

Graphic organizer is considered more effective to help students to construct historical argumentative reasoning for some reasons. It can be a tool of meaningful instruction, because it strengthens complex cognitive structure of the students (Hill, 2005) and makes knowledge stored in memory longer (Ivie, 1998). Graphic organizer represents the relations of ideas. Historical argumentative reasoning is a reasoning that relates ideas and represents the causal relation of historical events (van Drie \& van Boxtel, 2008) and in this research, it is called memory-bound reasoning (Brainerd \& Reyna, 1992). Memory-bound reasoning is a reasoning that contains historical contents learned from texts by students and the content learned has been stored in their memory. Graphic organizer as a summarization technique is considered to help students to construct relational knowledge (DiCecco \& Gleason, 2009; and Graney, 1992). Graphic organizer can depict cause and effect relations. In short, it can facilitate historical argumentative reasoning as a relational knowledge or causal-relational knowledge.

Baxendell (2003) mentions several types of graphic organizer: concept map, flow diagram or sequence chart, compare/contrast or venn diagram, cause and effect chart, main ideas and detail charts, attribute chart, and story map. A cause-and-effect diagram highlights the direct relationship between different events or concepts. This research uses the cause and effect graphic organizer based on some considerations. First, the outcomes of historical argumentative reasoning requires to make a set of causes. Students should have causal relational knowledge of an event. Secondly, the graphic organizer shows cause-effect relation. By constructing the cause and effect graphic organizer, the students construct causal relational knowledge.

Rationale for the present research was presented as follows. Graphic organizer is the instructional tool for meaningful learning, because it can strengthen the complex structure of the brain (Hill, 2005) and help knowledge stay longer in memory (Ivie, 1998). Graphic organizer represents the relationships of main ideas and topics of the reading text (Clark \& Mayer, 2008). Moreover, historical argumentative reasoning is a relationship of ideas that represents historical causal relationship (van Drie \& van Boxtel, 2008). Historical argumentative reasoning is memorybound reasoning (Brainerd \& Reyna, 1992), that is, reasoning that based on the learned materials stored in memory. Graphic organizer Summarization is a strategy to attain relational knowledge form the reading texts (DiCecco \& Gleason, 2009; Graney, 1992). Furthermore, it is possible that the structures of 
historical texts affect the summarization. Drawing from what we know about how students summarize texts and how the nature of text formats may increase the outcomes of the historical argumentative reasoning, the review of the literature lead us to the following hypotheses: (1) Summarization instructional strategies will affect the outcomes of historical argumentative reasoning; (2) Text formats will affect the outcomes of historical argumentative reasoning; (3) Summarization instructional strategies and text formats will interact.

\section{RESEARCH METHOD}

The $2 \times 2$ quasi experimental design comprised: two summarization instructional strategies (the graphic organizer construction and written summarization) and two presentation formats: present-subheadings and absentsubheadings. The present study examined the effects of summarization instructional strategies and presentation formats to the outcomes of historical argumentative reasoning. The factorial design was used to investigate the effects. SMA (Sekolah Menengah Atas/ Senior High School) students were randomly assigned to experimental groups. The number of subjects working on the experimental sessions was 135 twelfth students from classes taught by different teachers on four state-owned Senior High Schools in Kabupaten Malang, but 23 students either did not complete it or were missing data necessary to complete the analysis. Therefore, a total number of 112 students completed the study. Only data from the subjects who completed all phases of the study were used in the data analysis. The class sizes ranged from 26 to 38 students.

There were four experimental groups: Graphic Organizer Construct-
ing/Present-Subheadings Group, Graphic Organizer Constructing/ Absent-Subheadings Group, Written Summarizing/Present-Subheadings, and Written Summarizing/AbsentSubheadings Group.

All data analysis were carried out using SPSS Version 20. I compared the post-test using 2X2 ANCOVA with the pre-test score as a covariate. The two independent variables were summarization instructional strategies (studentconstructed graphic organizer and written summarizing) and presentation formats (present-subheadings and absentsubheadings). The dependent measure was the post-test score of historical argumentative reasoning questions. The covariate in the analysis was the score on the measure of pretest of historical argumentative reasoning questions similar to the post-test. The effects of the four conditions on the historical argumentative reasoning scores were tested by the means of the ANCOVA procedure.

\section{RESULTS AND DISCUSSION}

The statistical analysis are reported in Tabel 1. The two-way ANCOVA reveals a significant main effect for summarization instructional strategies on the outcomes of historical argumentative reasoning $(\mathrm{F}(1,107)=44.376, \mathrm{p}=$ $0,000)$. Besides, it reveals that the graphic organizer condition lead to be significantly higher $(\mathrm{M}=22,63)$ than the written summarizing condition $(M=18,49)$.

The two-way ANCOVA reveals no main effect for presentation formats on the outcomes of historical argumentative reasoning $(\mathrm{F}(1.107)=3.123, \mathrm{p}=$ $0.080)$. Subjects in the presentsubheadings $(\mathrm{M}=19.87)$ do not differ significantly from the absentsubheadings $(\mathrm{M}=21.00)$. 


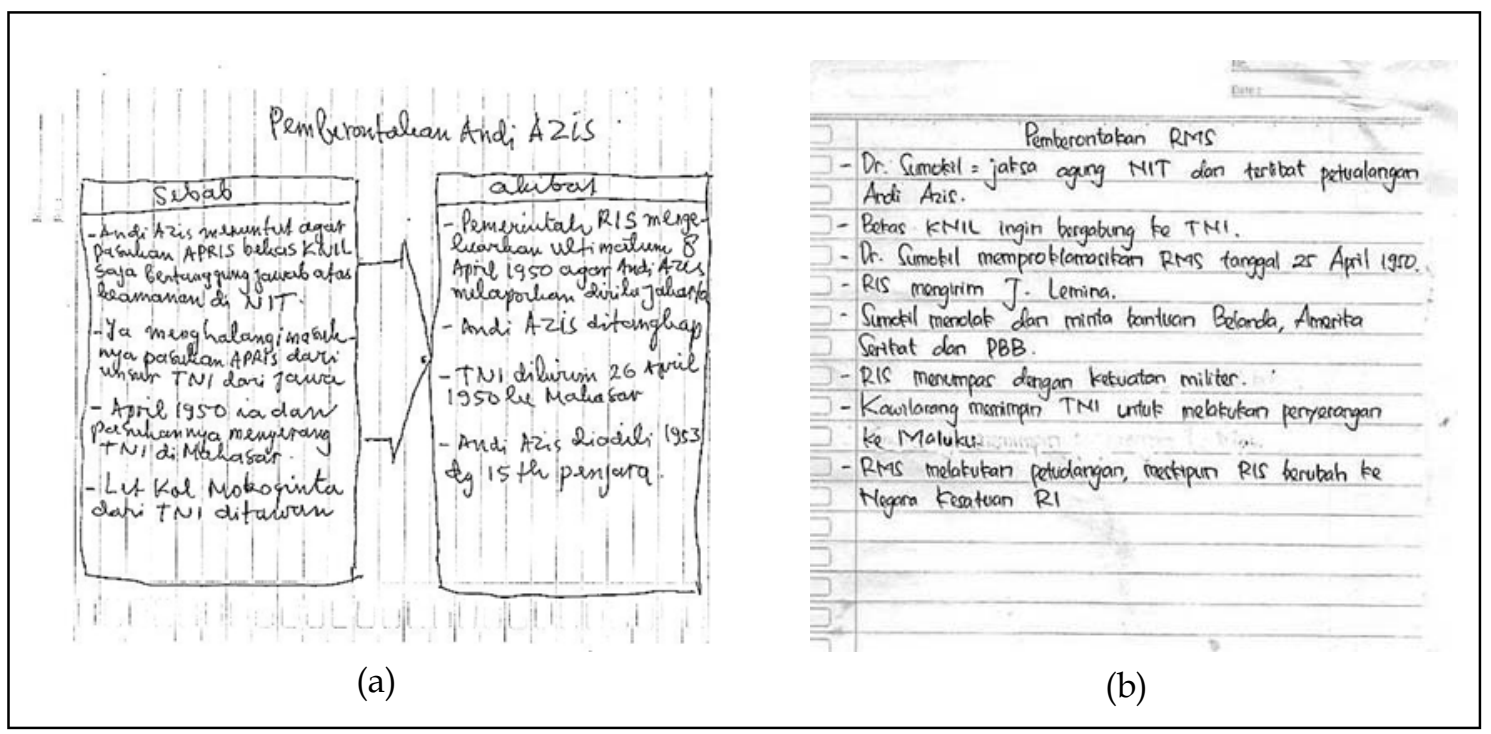

Notes:

(a) Student's graphic organizer summarizing

(b) Student's written summarizing

Figure 1. Sample of Student's Graphic Organizer \& Written Summarizing

The two-ways ANCOVA also reveal a significant interaction between summarization instructional strategy and presentation format $(\mathrm{F}(1.107)=$ $24.289, \mathrm{p}=0.000)$. While the subjects of the present-subheadings condition have relatively similar post-test scores regardless of summarization instructional strategies, subjects of graphic organizer condition are strongly affected by the presentation format, showing higher scores with the present-subheadings and lower with the absent-subheadings.

The effect of summarization instructional strategy on the outcomes of history argumentative reasoning

Summarization instructional strategies affected the outcomes of historical argumentative reasoning. The result showed that there were the differences on the post-test score of historical argumentative reasoning between causeeffect graphic organizer group and writ- ten summarizing group. The summarization instructional strategy of causeeffect graphic organizer was better than the summarization instructional strategy of written summarizing on the posttest scores.

Other research showed different results. Students in the graphic organizer condition got retention and transfer scores better than the other conditions (Stull \& Mayer, 2007), and got better scores in immediate recall, delayed recall dan transfer (Griffin et al., 1995). Other research findings that supported the result of this present study will be presented as follows. Students summarizing with graphic organizer got better scores significantly in recognition and recall than students summarizing without it (McCagg \& Dansereau, 1991). Students summarizing with graphic organizers got better scores in remembering main ideas than students who used the other strategies (Rewey et al., 1989).

Some explanations could be given to the result of this study. First, by con- 
structing cause-effect graphic organizers the students could construct cause-effect relationship of the historical text. The student-constructed graphic organizer showed cause-effect relationship. Historical argumentative reasoning in the present study required the students to construct explanation as a cause of its consequence event. The historical argumentative reasoning showed causeeffect pattern. The student-constructed cause-effect graphic organizer functioned as a frame or a structure that represented the content of the text. For this reason, after the students constructed cause-effect graphic organizer, they could easily answer historical argumentative reasoning questions. In short, the cause-effect graphic organizer facilitated the students to produce historical argumentative reasoning.

Students-constructed graphic organizer could frame the organization of information set (Idol-Maestas, 1985). It made the students to group information. Because the graphic organizers in the present research were constructed by the students in the form of causeeffect graphic organizers, then the graphic organizers grouped the information into the group of cause and the group of effect. Besides, the two sets of information were unified into causeeffect relationship patterns. The causeeffect relationship patterns facilitated the students to produce historical argumentative reasoning.

Secondly, according to depth processing theory (Meyer et al. in Hoffman, 2010), if the text structure was reorganized into the explicit structure, the text would be memorized better. It was caused by the student activelyreorganizing process. Based on the theory, the summarization of the historical texts in the form of cause-effect graphic organizer was the reorganization process of the text. Consequently, the infor- mation in the text would be assimilated in the student's memory.

Thirdly, generative learning occurs when the students generate a product (Wittrock, 1990). By producing the cause-effect graphic organizer, the students were doing the generative learning in reconstructing meaning and building the realtions among the parts of the text (Wittrock, 1992). By elaborating the reading text, it could promote the retention and the transfer (Grabowski, 2001). For the present study, the students who constructed the cause-effect graphic organizer that related the parts of the text were doing generative learning process. As a consequence, the structural information generated by the students would be memorized better.

When the students summarized a text, they had the holistic representation of the reading text (Wittrock \& Alesandrini, 1990). The text structures in the present study were arranged in the cause-effect structures. Moreover, the students summarized the texts into cause-effect graphic organizers. It was possible that the students would have the holistic representation of the causeeffect structure. In turns, it gave the access to answer historical argumentative reasoning questions in which the students retrieved the set of information in the form of causal events.

Fourthly, according to schema theory (Iran-Nejad, 1980; Ohlson, 1993; McVee et al., 2005), knowledge organized in a brain was the network of mental structure. Cause-effect graphic organizers were the networks of connected ideas (Slavin, 2000). The students -constructed cause-effect graphic organizers were the schema in the brain. Schema helped the students to relate among the propositions in the text, and it was a form of the relationship. In addition, it became an extra retrieval path (Smith \& 
Swinney, 1992), when the students were asked to retrieve information from the text. It was possible that the schemata would facilitate the students to retrieve causal relationships from the texts.

The cause-effect graphic organizer functioned as an ideational unit similar to the schemata. In other words, information in a cause-effect graphic organizer became the part of the students' cognitive structure, so they could relate and store the information easily. Consequently, the students' cause-effect graphic organizer as a content organizing tool would help more than the detailed-written summarization.

Fifthly, according to cognitive load theory (Artino JR, 2008; Van Merienboer \& Sweller, 2005), the complexities of the reading text would be the extraneous cognitive load. By constructing the cause-effect graphic organizer, the students would omit trivial information, so the left information was important information and it showed the relationship. The studentsconstructed cause-effect graphic organizer would reduce the extraneous cognitive load. For this reason, when the students were asked to answer the historical argumentative reasoning questions as the retrieval of the causal relationship, the students would be easily able to retrieve the causal information.

Sixthly, according to dual coding theory, a cause-effect structure could promote integrative imagery that facilitated retrieval (Clark \& Paivio, 1991). The spatial network on the cause-effect graphic organizer represented the associative knowledge that functioned as the associative mechanism. The pattern of the cause-effect graphic organizer was imagined as cognitive map and it represented a linked sequence of phenomena.

The causal knowledge structure built in the cause-effect graphic organiz- er facilitated the students to do verbal associative processes. When the students were asked to answer reasoning questions or causal reasoning questions, then the students would be facilitated those by the cause-effect graphic organizer in the verbal associative process form. The effect event would caused referent, so it facilitated the students to answer historical argumentative reasoning questions that required the students to identify the causal events.

\section{The effect of presentation format on the outcomes of history argumentative reasoning}

The result of the study found that there were no differences on the outcomes of the historical argumentative reasoning between the presentsubheadings presentation format group and the absent-subheadings presentation format group. The fact that subheadings did not affect the performance of the students suggested that subheadings did not help the students in comprehending the historical texts. In short, the subheadings did not promote the historical argumentative reasoning posttest scores.

Some previous research findings showed inconsistencies. Subheadings could promote reading comprehension, but it depended on the length and the difficulty level of the texts (Spyridakis \& Standal, 1987). Students reading the texts with subheadings could answer transfer tests better than without subheadings (Mautone \& Mayer, 2001). Subheadings affected significantly in answering main idea questions and recognition but it was not in details (Wilhite, 1989). Subheadings strengthened the text organization and made the general representation of the text clear (Wilhite, 1986). Two other research find- 
ings supported the results of this present study. Subheadings did not facilitate to memorize the text topics (Lorch et al., 1993). Subheadings were not beneficial to the students' recall.

The possibility that there were no differences on the outcomes of historical argumentative reasoning between the present-subheadings presentation format group and the absent-subheadings presentation format group can be explained as follows. The subheadings helped the students on the structure of the texts but not the details. They helped the students remember the title, the structure and the main ideas. On the other hand, they did not help the subject remember causal historical facts as a relation.

Subheadings helped the students to construct the cause-effect graphic organizers. They did not help the subject remember in details. The cause-effect graphic organizer directed the subject to construct the structure of the relational knowledge. Subheadings made the subject easier to construct the cause-effect graphic organizer. Then, the subheadings functioned well in the process of the cause-effect graphic organizer construction, but they could not promote the posttest score of historical argumentative reasoning.

Because the historical texts in the study were short texts, the subheadings did not much help the students to comprehend the organizational structure of the texts. It was possible that if the texts were long texts, then the subheadings were much more helpful for the students to comprehend the organizational structure of the texts. Of course, the subheadings did not make the relations of the text parts explicit. For this reason, for the short texts in the study the subheadings did not help the students in answering the historical argumentative reasoning questions which asked the subject to construct causal relational answers.

The historical texts in the study could be comprehended easily by the subjects. The text complexity was low, so it was not difficult for the subject to comprehend the historical texts. For this reason, subheadings did not help the subject to understand the content of the texts. They did not affect the post-test score of the historical argumentative reasoning.

Subheadings in the study informed the main ideas of the texts. Of course, they could benefit to the students to answer the questions that asked main ideas. However, the questions in the study asked the subject to transform the ideational subheadings into the cause and effect subheadings. It meant that the first subheading of the experimental texts was actually the cause subheading and the second subheading was the effect subheading. The result would be different if the first subheading was labeled the cause and the second subheading was labeled the effect. As we knows, the questions in the study asked the students to construct the cause statements of an event. In other words, the students were asked to write the factual statements of the first subheading as the historical argumentative reasoning answer. Because of this, the students got difficult to answer historical argumentative reasoning questions even though they read the present-subheadings presentation format.

Subheadings could be signals to answer the questions of main ideas, but to this study, the questions did not ask main ideas. The questions in the study asked the students to construct a set of evidences, conclusions, facts or events as a causal knowledge. Even though subheadings were present, they did not help the students to produce historical argumentative reasoning answers as causal answers. 
The reasons why subheadings did not affect the post-test scores of historical argumentative reasoning can be concluded as follows. Subheadings functioned well in processing the long texts. On the other hand, the texts of the study were short texts. So, the subheadings did not much help in processing the short texts. In other words, whether the subheadings were present or not, they did not affect in promoting the post-test score of historical argumentative reasoning.

\section{The Effect of the Interaction}

The research finding showed that the summarization instructional strategies interacted with the presentation formats on the post-test scores of the historical argumentative reasoning. It operationally showed that the students of the cause-effect graphic organizer group were much better than the students of the written summarizing group on the historical argumentative reasoning posttest scores. The students of the graphic organizer group had higher scores with the present-subheadings presentation format. The significant interaction of the summarization instructional strategies and the presentation formats revealed that the student-constructed cause-effect graphic organizer was more helpful to construct causal-relational knowledge.

The post-test scores from the students of the cause-effect graphic organizer group receiving the presentsubheadings presentation format were better than the other three groups. In other words, one level of the summarization instructional strategy could not stand alone in affecting the post-test score of historical argumentative reasoning, but it depended on the presentsubheadings presentation format. It meant that the summarization instruc- tional strategies depended on the presentation formats. They dependeded on each other (Shavelson, 1981).

The previous research did not much report the interaction between the presentation format and other variables. Subheadings presentation format did not interact significantly with the prior knowledge (Wilhite, 1989). Subheadings interacted with text characteristics (Spyridakis \& Standal in Lorch et al., 1993). Subheading frequency interacted significantly with presentation medium (Bartell, 2006).

It is needed further to explain why the summarization instructional strategy of cause-effect graphic organizer interacted with the present-subheadings presentation format in the present study. Subheadings seemed to facilitate in constructing the cause-effect graphic organizer. Subheadings made the students focusing on the text structure or the text organization, so it could help the students in constructing the causeeffect graphic organizer. The Graphic organizers in this study were the causeeffect graphic organizers. The text structure represented in the subheadings were transformed by the students to cause-effect graphic organizer construction. In short, the text structure made the students easily moving information in the text to the form of cause-effect graphic organizer.

Why the text structure made the students easily transforming the information in the text to the cause-effect graphic organizer can be explained as follows. Two subheadings of the historical text automatically divided the text into two parts namely the cause part and the effect part. Moreover, based on the two parts the text information would be easily inserted by the students into the cause-effect graphic organizer. In turns, the interaction between the cause-effect graphic organizer and pre- 
sent-subheadings presentation format could promote the outcomes of historical argumentative reasoning.

\section{CONCLUSION}

Three conclusions are drawn from the results of the present study. First, the experiment demonstrated that summarization instructional strategies affected the outcomes of historical argumentative reasoning. This finding supports McCagg \& Dansereau's (1991) success in using graphic organizer construction to enhance instructional outcomes. It supports to the effectiveness of the strategy to remember the main ideas (Rewey et al., 1989).

Second, the research demonstrated that presentation formats did not affect the outcomes of historical argumentative reasoning. Whether the subheadings were present or not, they did not affect the construction of historical argumentative reasoning answer.

Thirdly, the research also demonstrated that summarization instructional strategies interacted with presentation formats to affect the outcomes of historical argumentative reasoning. Even though subheadings did not show explicitly a cause and effect structures that would be represented in the historical argumentative reasoning answers, they helped students to summarize the cause -effect graphic organizer. Consequently it could help the students to answer the historical argumentative reasoning questions. It can be concluded that summarization instructional strategies depend on presentation formats to affect the outcomes of historical argumentative reasoning.

\section{ACKNOWLEDGEMENT}

I thank the members of my dissertation committee: Prof. Dr. I Wayan Ardhana, MA., Prof. Dr. I Nyoman Sudana Degeng, and Dr. Waras Kamdi, for their insightful comments, valuable recommendations, helpful discussions and suggestions for this research. All remaining erros are mine.

\section{REFERENCES}

Alvermann, D. E. 1986. Graphic organizers: cuing devices for comprehending and remembering main ideas. In James $F$. Baumann. Teaching main ideas comprehension. Newark, Del: International Reading Association.

Armbruster, B. B., Anderson, T. H., \& Meyer, J. L. 1991. Improving content area reading using instructional graphics. Reading Research Quarterly, 26 (4): 393416.

Baxendell, B. 2003.Graphic organizer: guiding principles and effective practices. Diakses pada tanggal 16 Februari 2012 darihttp://education.wm.edu/ centers/ttac/documents/packets/ graphicorganisers.pdf

Brainerd, C. J. \& Reyna, V. F. 1992. Explaining memory-free reasoning. Psychological Science, 3 (6): 332-339.

Braselton, S. \& Decker, B. C. 1994. Using graphic organizers to improve the reading of mathematics. The Reading Teacher, 48 (3): 276-280.

Chang, K. E., Sung, Y. T. \& Chen, I. D. 2007. The effect of concept mapping to enhance text comprehension and summarization. The Journal of Experimental Education, 7 (1): 5-23.

Darch, C. B., Carnie, D. W., \& Kameenui, E. J. 1986. The role of graphic organizers and social structure in content area instruction. Journal of Reading Behavior, 18 (4): 275-295.

De La Pas, S., Morales, P., \& Winston, P. M. 2007. Source interpretation: teaching students with and without LD to read and write historically. Journal of 
Learning Disabilities, 40 (2): 134-144.

De Ramos, J. T. 2010. A study on schema activation, summarizing, and critical evaluation as predictors of writing proficiency. The International Journal of Research and Review, 5: 31-39.

DiCecco, V. M., \& Gleason, M. M. 2002. Using graphic organizers to attain relational knowledge from expository text. Journal of Learning Disabilities, 35 (4): 306-20.

Duron, R., Limbach, B., \& Waugh, W. 2006. Critical thinking framework for any discipline. International Journal of Teaching and Learning in Higher Education, 17 (2): 160 -166.

Facione, P. A. 2007. Critical thinking: what it is and why it counts. Millbrae, CA: California Academic Press.

Friend, R. 2001. Teaching summarization as a content area reading strategy. Journal of Adolecent $\mathcal{E}$ Adult Literacy, 44 (4): 320-329.

Gajria, M., \& Salvia, J. 1992. The effects of summarization instruction on text comprehension of students with learning disabilities. Exceptional Children, 58 (6): 508-516.

Graney, J. M. 1992. A framework for using text graphing. System, 20 (2): 161-167.

Hill, L. H. 2005. Concept mapping to encourage meaningful student learning. Adult Learning, 16 (3/4): 7-13.

Hwang, G., \&Kuo, F. R. 2011. An information-summarizing instruction stratetgy for improving the webbased problem solving abilities of students. Australian Journal of Educational Technology, 27 (2): 290-306.

I s k a n d a r, M ., Sun a r i , L ., \&Abdurahman.2007, Sejarah SMA Kelas XII Program Bahasa. Bandung: Ganeca Exact.

Ivie, S. D. 1998. Ausuble's learning theory: an approach to teaching higher order thinking skills. High School Journal, 82 (1): 35-43.

Kang, S. 2004. Using visual organizers to enhance English as Foreign Language instruction. English Language Teaching Journal, 58 (1): 58-67.

Key, L. V., Bradley, J. A., \& Bradley, K. S. 2010. Stimulating instruction in social studies. The Social Studies, 101: 117120.

Kim, A. H., Vaughn, S., Wanzek, J., \& Wei, S. 2004. Graphic organizers and their effects on the reading comprehension of students with Learning Disabilities: a synthesis of research. Journal of Learning Disabilities, 37 (2): 105-118.

King, J. R., Biggs, S., \& Lipsky, S. 1984. Students' self-questioning and summarizing as reading study strategies. Journal of Reading Behavior, 16 (3): 205218.

Kools, M., van de Weil, M. W. J., Ruiter, R. A. C., Cruts, A., \& Kok, G. 2006. The effect of graphic organizers on subjective and objective comprehension of a health education text. Health Education $\mathcal{E}$ Behavior, 33 (6): 760-772.

Malone, L. D., \& Mastropieri, M. A. 1991. Reading comprehension instruction: summarization and self-monitoring training for students with learning disabilities. Exceptional Children, 52 (3): 270-279.

Massey, D. D. \& Heafner, T. L. 2004. Promoting reading comprehension in social studies. Journal of Adolescent $\mathcal{E}$ Adult Literacy, 48 (1): 26-40.

McCagg, E. C. \& Dansereau, D. F. 1991. A convergent paradigm for examining knowledge mapping as a learning strategy. Journal of Educational Research, 84 (6): 317-324.

Mustopo, M. H., Hermawan, Sugiarti, \& Supriyono, A. 2008. Sejarah Kelas XII Bahasa. Jakarta: Yudhistira.

Nesbit, J. C. \& Adesope, O. O. 2006. Learning with concept and knowledge maps: a meta-analysis. Review of Educational Research, 76 (3): 413-448.

Neufeld, P. 2005. Comprehension instruction in content area. The Reading Teacher, 59 (4): 302-312.

Neumann, D. J. 2010. “What is the text doing?" preparing preservice teachers to teach primary sources effectively. The History Teacher, 43 (4): 492-511.

Novak, J. D. \& Canas, A. J. 2008. The theory underlying concept maps and how to construct and use them. Technical Report IHMC Cmap Tools 2006-01 RW 012008. Florida Institute for Human and 
Machine Cognition.

Ohlson, S. 1993. Abstract schemas. Educational Psychologist, 28 (1): 51-56.

Paxton, R. J. 1999. A deafening silence: history textbooks and the students who read them. Review of Educational Research, 69 (3): 315-339.

Permendikbud RI Nomor 69 Tahun 2013 tentang Kerangka Dasar dan Struktur Kurikulum Sekolah Menengah Atas/ Madrasah Aliyah. Jakarta: Departemen Pendidikan dan Kebudayaan.

Presley, M. 2000. What should comprehension instruction be the instruction of? Dalam M. L. Kamil, P.B. Mosenthal, P. D. Pearson, \& R. Barr (eds). Handbook of reading research. Volume 3, pp. 545561. Mahwah, NJ: Erlbaum.

Rael, P., 2005. What happened and why? Helping students read and write like historians. The History Teacher, 39 (1): 24-32.

Rewey, K.L, Dansereau, D.F., Skages, L.P., \& Hall, R. H. 1989. Effects of scripted cooperation and knowledge maps on the processing of technical material. Journal of Educational Psychology, 81 (4): 604-609.

Robinson, D. H., \& Schraw, G. 1994. Computational efficiency through visual argument: do graphic organizers communicate relations in text too effectively? Contemporary Educational Psychology, 19: 399-415.

Robinson, D. H., \& Kiewra, K. A. 1995. Visual argument: graphic organizers are superior to outlines in improving learning from text. Journal of Educational Psychology, 87 (3): 455-467.

Robinson, D. H., Corliss, S.B., Bush, A. M., Bora, S. J. \& Tomborlin, T. 2003. Optimal presentation of graphic organizers and text: a case for large bites? Educational Technology, Research and Development, 51 (4): 25-41.

Sekretariat Negara RI. 1986. 30 tahun Indoensia merdeka 1945-1949 Jilid 1 Cetakan ke 7. Jakarta: PT Citra Lamtoro Gung Persada.

Senen, A., \& Barnabib, I. 2000. Tantangan guru sejarah: pesan sejarah sebagai konsep pendidikan nilai. Jurnal Penelitian dan Evaluasi, 2 (3): 131-140.
Sirias, D. 2002. Using graphic organizers to improve the teaching of business statistics. Journal of Education for Business, 78 (1): 33-37.

Smith, E. E. \& Swinney, D. A. 1992. The role of schemas in reading text: a real time examination. Discourse Processes, 15: 303-316.

Spicer, D. P. 1998. Linking mental models and cognitive maps as an aid to organizational learning. Career Development, 3 (3): 125-132.

Supriatna, N. 2007, Sejarah SMA Kelas XII Program Bahasa. Bandung: Penerbit Grafindo Media Pratama.

Taylor, B. M. 1986. Teaching middle grade students to summarize content textbook material. In James F. Baumann. Teaching main ideas comprehension. Newark, Del: International Reading Association.

Trevino, C. 2005. Mind mapping and outlines comparing two types of graphic organizers for learning seventh-grade life science. Disertasi. Texas Tech University.

Van Drie, J., \& Van Boxtel, C. 2008. Historical reasoning: towards a framework for analyzing students ' reasoning about the past. Educational Psychology Review, 20 (2): 87-110.

Van Sledright, B. A. 2004. What does it mean to read history? Fertile ground go cross-disciplinary collaborations? Reading Research Quarterly, 39 (3): 342346.

Voss, J. F. \& Wiley, J. 1995. Acquiring intellectual skills. Annual Review of Psychology, 46: 155-181.

Wineburg, S. S. 1991. On the reading of historical texts: notes on the breach between school and academy. American Educational Research Journal, 28 (3): 495 -519 .

Yilmas, K. 2009. A vision of history teaching and learning: thoughts on history education in secondary schools. The High School Journal, 92 (2): 37-46.

Zaini, S. H., Mokhtar, S. Z., \& Nawawi, M. 2010. The effect of graphic organizer on students' learning in school. $\mathrm{Ma}$ laysian Journal of Educational Technolo$g y, 10(1): 17-23$. 